\section{> Gjesteskribent}

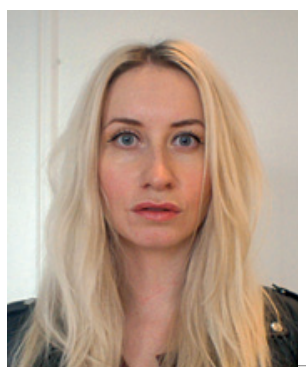

\section{Vibeke Ottesen}

Kriminolog og gjesteforsker ved Senter for økologisk

og evolusjonær syntese (CEES)

Universitetet i Oslo

\title{
Har pasienten din drapstanker?
}

\author{
Ved å spørre pasienter som går \\ gjennom kriser i livet om de har \\ hatt drapstanker, mener jeg fast- \\ leger kan bidra til å fjerne tabuet \\ rundt slike tanker og bidra til \\ å forhindre drap.
}

Drap i nære relasjoner utgjør omtrent en tredel av alle drap i Norge. I vårt land er det likevel ikke på snart 30 år publisert forskning på hvilke grupper av individer som har en sårbarhet for slike drap og hvilke situasjoner som kan være utløsende. I anledning at jeg skriver en doktoravhandling som omhandler drap og drapsforskning i Norge, får jeg ofte spørsmål om det er noe som kan gjøres for å forhindre drap mens vi venter på forskningen. Svaret mitt er at vi kan begynne arbeidet med å fjerne tabuet rundt det at noen kvinner og menn får drapstanker når de opplever kriser i livet sitt. Jeg mener fastlegen har en viktig rolle i dette arbeidet.

For dem som ikke jobber med temaet drap til daglig, er det kanskje vanskelig å tro at en mor kan gå med tanker om å drepe sitt barn, eller at en mann kan gå med tanker om å drepe sin kone. Men forskning fra andre land viser at det ikke er uvanlig at kvinner og menn som begår drap i nære relasjoner, har gått med drapstanker over tid i forkant av drapet. Det er heller ikke uvanlig at de har oppsøkt det medisinske hjelpeapparatet i nær forkant av drapet. De har imidlertid ikke fortalt om drapstankene sine til hjelpeapparatet, og har da heller ikke fått hjelp med å komme seg bort fra tankene.
For både kvinner og menn kan det å oppleve at de ikke kan ta godt vare på sine barn, være en krise som utløser tanker om å begå barnedrap. For kvinner kan dette være å oppleve å ikke strekke til som omsorgsgiver, for eksempel på grunn av at de sliter med en depresjon. For menn kan dette være å oppleve å ikke strekke til som fors $\varnothing$ rger, som for eksempel ved å miste jobben sin eller være i økonomisk uføre. Hvor rart det enn kan høres ut, så kan forelderen få tanker om at barnet vil få det bedre om det slipper å leve under de gitte forholdene. Dette ønsket om å beskytte barnet gjennom døden er også tanken som melder seg hos både kvinner og menn som planlegger å ta sitt eget liv og som ønsker å ta barna med seg inn i døden.

Noen menn som opplever å ikke strekke til som fors ørger, kan få tanker om å drepe sin partner i tillegg til barnet. Noen menn kan også få tanker om å drepe sin partner og også sine barn når partneren ønsker seg ut av forholdet. Kvinner begår sjelden partnerdrap og enda sjeldnere familiedrap. Når kvinner får tanker om partnerdrap, er det som oftest når de opplever at de ikke har noen annen trygg vei ut av et voldelig forhold.

Fastlegen har en unik mulighet til å kunne gjenkjenne pasienter som opplever disse krisene i livet sitt, dersom de har et oppmerksomt forhold til sine pasienter. Ved å spørre aktuelle pasienter på en ikke-fordømmende måte om de har hatt drapstanker, kan fastlegen ta det initiativet som kanskje skal til for at pasienten opplever det som trygt å snakke om de tabubelagte tankene. I det fortrolige forholdet til fastlegen kan pasienten forhåpentligvis få hjelp til å se andre løsninger på krisen enn drap, eller bli henvist til andre instanser.

Det er viktig å vite, både for legen og for pasienten, at ikke alle som har drapstanker vil begå drap. Men det er like viktig å vite at drapstanker kan komme når man gjennomgår kriser i livet som oppleves som overveldende. Og av og til kan krisen være så overveldende at en så drastisk handling som drap kan fremstå som en reell løsning.

Noen synes kanskje at forslaget om at fastleger skal spørre enkelte av sine pasienter om de har drapstanker er kontroversielt. Hva om man trigger tanker om drap som ellers ikke ville ha oppstått? Og hva om pasienten blir støtt av at man spør om hun eller han har hatt drapstanker? Jeg vil da minne om at dette var bekymringer man tidligere har hatt rundt det å spørre om selvmordstanker. I våre dager vet vi at det å spørre om noen har slike tanker, kan være akkurat den håndsutstrekningen som gjør det lettere for den det gjelder å be om hjelp. Nå er tiden inne for å fjerne tabuet rundt drapstanker!

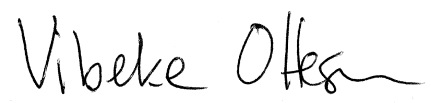

